JOURNAL

p-ISSN

e-ISSN

PUBLISHER
International Journal of Innovative Technologies in Economy $2412-8368$

2414-1305

RS Global Sp. z O.O., Poland
ARTICLE TITLE

$\operatorname{AUTHOR}(\mathbf{S})$

ARTICLE INFO

DOI

RECEIVED

ACCEPTED

PUBLISHED

LICENSE
MODERN DEVELOPMENT TRENDS OF THE FOREIGN TRADE IN THE CONTEXT OF POLAND AND AZERBAIJAN

Toghrul Allahmanli

Toghrul Allahmanli. (2020) Modern Development Trends of the Foreign Trade in the Context of Poland and Azerbaijan. International Journal of Innovative Technologies in Economy. 5(32). doi: 10.31435/rsglobal_ijite/30122020/7228 https://doi.org/10.31435/rsglobal_ijite/30122020/7228

05 October 2020

07 November 2020

12 November 2020

\section{(a) (1)}

This work is licensed under a Creative Commons Attribution 4.0 International License.

(C) The author(s) 2020. This publication is an open access article. 


\title{
MODERN DEVELOPMENT TRENDS OF THE FOREIGN TRADE IN THE CONTEXT OF POLAND AND AZERBAIJAN
}

\author{
Toghrul Allahmanli, \\ Ph.D., The University of Lodz, Poland
}

DOI: https://doi.org/10.31435/rsglobal_ijite/30122020/7228

\author{
ARTICLE INFO \\ Received 05 October 2020 \\ Accepted 07 November 2020 \\ Published 12 November 2020

\section{KEYWORDS} \\ International economic, \\ relations, \\ economic-theoretical \\ concepts, \\ classics, \\ neoclassicals, \\ economic relations of \\ Azerbaijan and Poland.
}

\begin{abstract}
The collapse of the Soviet empire led countries to gain their independence. Azerbaijan was one of these countries in a country with a very centuries-old history. The Republic of Azerbaijan, which declared its independence in 1991, underwent reforms to restore its economy. The main goal was to change the mechanism of governing the economy left over from Communism. He first signed the Contract of the Century in 1994. At the same time, it stimulated the development of not only economic relations but also international relations. At the same time, the genocide committed by Armenians in 1989 was a great blow to the people of Azerbaijan. It has been 30 years since the occupation of up to $20 \%$ of the territory of Azerbaijan and the failure of the Armenians to return the occupied lands.

At a time when capitalism is at its peak in the age of globalization, the unexpected COVID-19 virus, which has frightened the whole world, is causing unexpected damage to the world economy. One of them was Azerbaijan. At a time when capitalism is at its peak in the age of globalization, the unexpected COVID-19 virus, which has frightened the whole world, is causing unexpected damage to the world economy. One of them was Azerbaijan. The shrinking of Azerbaijan's economy to $4 \%$ will lead to the development of new reforms in one way or another.

Azerbaijan's economy, based on a market economy, will be hampered by both a pandemic and the fact that the neighboring country is at war. According to forecasts, the country's economy is expected to shrink by $10 \%$.

Azerbaijan's relations with Poland, one of its main Western allies, are helping both in economic and other terms. Azerbaijan is a country with its products in the European market. Relations with Poland, a key partner, are growing stronger.
\end{abstract}

Citation: Toghrul Allahmanli. (2020) Modern Development Trends of the Foreign Trade in the Context of Poland and Azerbaijan. International Journal of Innovative Technologies in Economy. 5(32). doi: 10.31435/rsglobal_ijite/30122020/7228

Copyright: (C) 2020 Toghrul Allahmanli. This is an open-access article distributed under the terms of the Creative Commons Attribution License (CC BY). The use, distribution or reproduction in other forums is permitted, provided the original author(s) or licensor are credited and that the original publication in this journal is cited, in accordance with accepted academic practice. No use, distribution or reproduction is permitted which does not comply with these terms.

Azerbaijan is a country with more economic potential and promising perspectives among the South Caucasian states. Its rich hydrocarbon deposits, oil reserves, as well as climatic conditions favorable for agriculture, require substantial economic projects and investment. What is happening in the geo-economic landscape of the Caspian-Black Sea basin and the South Caucasus is the reason for the growing interest of the world in the interest of this area and the broader opportunities for economic success. The East-West relations, the implementation of large and promising projects, the creation of more favorable conditions for transnational world interests in transport and communications. The geoeconomics and geopolitical landscape of the region has led to the fact that the political, economic power centers of the world have developed here. The policy pursued by Azerbaijan in such a variety of spheres based on the establishment of mutually beneficial relationships, raising the well-being of the population, and the acquisition of serious partners. The economic policy pursued by Poland also serves 
to them, their high ideals and economic opportunities through its content and genetic function. Because both Azerbaijan and Poland have a specific weight in the region. Its economic indicators and dynamics of growth are attributable to the emergence of natural gardens, the need to predict the needs, to ensure the dynamics of development based on new technologies, and the sustainability of successful economic processes in various fields. Poland is one of the developed states of Central Europe and has a specific weight in the region. The successful policy pursued by him in the economic sphere is taken as an important fact of mutual relations and improvement of welfare of the country.

Z.K. Brzezinski, who commented on political issues, first emphasized Azerbaijan's integration to the West in its work to reduce dependence [1]. Because the strengthening of Azerbaijan is economic and political, position creates a strong impetus to the geo-economic view of the region, thus reducing dependence. Economic processes in the Caspian basin have been realized through the implementation of transnational projects. The strengthening of Kazakhstan's position in the Central Asia in the Caucasus has added to the geo-economic processes of the region and has led to the implementation of a free economic policy. The active position of Azerbaijan in the West-East context is an indication of its presence in the world markets with a more serious weight of independent and decisive step in the implementation of transnational projects. As a result of all this, Azerbaijan promises great prospects in terms of meeting economic needs with European countries, free market access, bringing new technologies into the country's economy, creating investment flows, exporting products to foreign markets, raising quality indicators and implementing joint projects. From this point of view, more attention is being paid to the establishment and strengthening of economic relations with Poland in economic relations. The export potential of Azerbaijan, as we know, was more dominant than oil and the fact that the economy of the oil sector represented one area.

In the Table 4, shows the Republic of Poland is also in the export and import relations and the dynamics of these relations have been characterized by a positive view of Azerbaijan since its independence.

Table 4. Azerbaijan's trade relations with Poland and its neighbors (thousand, USD dollar)

\begin{tabular}{|c|c|c|c|c|c|c|c|c|c|}
\hline Countries & 2008 & 2009 & 2010 & 2011 & 2012 & 2013 & 2014 & 2015 & 2016 \\
\hline Total & 54926021,1 & 20824469,3 & 27960821,8 & 36326867,0 & 33560854,4 & 34687919,3 & 31016306,5 & 21945815,6 & 17675727,3 \\
\hline $\begin{array}{c}\text { Russian } \\
\text { Federation }\end{array}$ & 1933258,0 & 1818498,5 & 1918560,5 & 2828452,0 & 2338254,6 & 2583022,8 & 1954751,7 & 1855692,3 & 2051082,5 \\
\hline Ukraine & 739354,8 & 695786,6 & 1354197,8 & 1467096,1 & 625318,1 & 864689,2 & 468021,7 & 333129,0 & 334177,9 \\
\hline Germany & 804136,7 & 640949,2 & 616973,9 & 1368654,9 & 1744738,6 & 2179759,7 & 2629200,3 & 1913958,5 & 1010023,4 \\
\hline Lithuania & 26279,5 & 14934,8 & 28252,1 & 25044,4 & 24007,0 & 21788,4 & 30349,0 & 27454,8 & 17259,9 \\
\hline Poland & 122011,8 & 33010,9 & 31492,3 & 122627,2 & 48738,8 & 56697,5 & 78678,7 & 97243,9 & 74984,0 \\
\hline Slovakia & 13773,7 & 11138,7 & 18233,8 & 19116,1 & 26278,2 & 24114,4 & 19066,9 & 21641,8 & 21610,8 \\
\hline
\end{tabular}

Source: https://www.stat.gov.az/source/trade/

However, the successful economic policy pursued by the state implies the development of alternative areas as a priori. Finally, as a result, reducing dependence on oil has become a goal and serious steps have been taken in the field of agriculture development. Crop, cotton, animal husbandry, horticulture, viticulture and so on. The great work done in the area would undoubtedly make a serious representation of the country's agricultural presence in the European markets in the near future. It promises special perspectives as the most promising line for further development of economic relations with Poland.

Along with other issues in the last official visit of the President of the Republic of Azerbaijan to Poland (26-28 June 2017), establishment of economic relations and defining perspective directions of development kept in focus. The business forum is focused on the work on these issues. Polish industry diversity, shipbuilding, textile, chemistry, forestry, metal industry, automotive, aircraft, machinery, cement, aluminum, woodworking, paper industry, mining and mining industries and so on, is of particular importance for the development of economic relations. The rich flora and fauna of Azerbaijan, its natural resources and climatic conditions attract more attention to the co-operation with the Polish Republic and the implementation of joint projects. Economic cooperation and cooperation opportunities between Azerbaijan and Poland have always been in the spotlight as a serious issue. Here, too, the increase in commodity turnover is of particular importance. For example, the trade 
turnover between the two countries increased by $\$ 10$ million in 2014 compared to 2013 and reached $\$ 140$ million. This growth has been observed in subsequent years and has created a diversity of goods. Conducting seminars in Baku in terms of cooperation with Polish companies serves to strengthen economic ties and identify alternative options. An example of this is the interest in the agricultural sector. The Polish delegation was represented at the international food fair in Baku.

One of the most important aspects of the perspective development of the field-scale economic relations is the investment that can be achieved with the successful use of it. Here, of course, concessions and concessions must kept in focus. With the establishment of an internationally competitive system, investments in various sectors of agriculture and the accuracy of its direction and the benefits of utilizing high technology opportunities are justified. Because of Azerbaijan's climate, soil fertility and accessibility of agricultural products, Poland's investors have increased interest in the field economy. The joint activity of Azerbaijan and Poland characterized by serious consequences such as the strengthening of its place in the international division of labor, its specialization in certain products.

One of the priorities of the Poland-Azerbaijan Intergovernmental Commission on Economic Cooperation is the establishment of economic relations. Participation of 500 Polish companies in the latest business forum and the implementation of joint business agreements determine prospects for individual fields. To study the pace of development of economic relations, it is enough to give an idea of import-export indicators only at the next stage of 2010. According to Poland's Central Statistical Bureau, trade turnover between the two countries amounted to \$51.5 million in January-July 2010. $\$ 45.2$ million of this turnover was exported from Poland to Azerbaijan, and $\$ 6.5$ million fell to imports.

Azerbaijan is in economic relations with the legal and physical persons of 147 countries of the world in 2014. One hundred eight countries exported goods and imported goods from 135 countries. Forty-four of them fall into the European countries, 33 to America, and 43 to Asia. All this is a common sight of Azerbaijan's economic ties, and an important part of it serves to establish economic relations with Poland. There is a wide network of student exchanges ranging from student exchange to tourism, such as the engineering and chemical industries, agrarian industry, metallurgy, forestry (furniture), furniture production, construction materials and construction, light industry, heavy industry, shipbuilding, textile, wood products, metal industry, automotive, aircraft, machinery, cement, aluminum, woodworking and paper industries, mining and mining industries. Student exchange also plays an important role in the development of regional economics and the Polish side is implementing a large number of scholarship programs for Azerbaijani citizens. This is of great importance as an important fact of the educational strategy implemented by the state. The Polish Culture and Language Center is the basis for the regulation of education, science and culture.

The economic relations between the Republic of Azerbaijan and the Republic of Poland are as follows: grain, cotton, fruits and berries, vegetables, potatoes, melons, grapes, sugar beet, sunflower, tea leaves, meat, milk, wool, sheep and cattle, electricity, gas and steam, wastewater treatment and refining, oil sector; processing section: manufacture of food products, beverage production, production of textile products, production of chemical products, production of construction materials, manufacture of finished metal products, production of metallurgical industry, production of electrical equipment, production of cars and trailers, jewelry, sports and medical equipment's, installation and repair of machinery and equipment and so on. This, in turn, creates the necessary laws, experience, necessary acts and institutional arrangements for the regulation of foreign trade. Because the principle, norms and rules adopted for everyone in international economic relations are calculated on a one-toone basis for the establishment and success of relations. Legal, administrative and organizational basis for the regulation of foreign economic relations creates conditions for maintaining and maintaining the country's economic ties and participation in the division of labor.

The specialization of Azerbaijan and Poland in the field of economic relations in certain economic products creates conditions for the establishment of economic advantages and the achievement of successes in this field. Here, the organization of a more efficient work of the national economy is observed and gives rise to additional investments. Rates of production of production vehicles and consumer goods formed. More precisely, economic ratios arise and even lead to land rates. The processes taking place in recent years have resulted in economic zones, landscapes and economic specialization. For example, reforms in specific regions of Azerbaijan, cotton making, viticulture, animal husbandry or industry-specifications are an example. In the economic view of Poland, there are promising areas for the development of the regional economy, which is of particular 
importance in terms of perspective directions of economic relations. Therefore, Poland and the Republic of Azerbaijan have formed a good partner in terms of investing, reliable and prospective partnership, economic cooperation, and the state's economic policy. From the viewpoint of the development of forestry, furniture and wooden industry, Poland is well aware of the fact that it is crucial for economic relations. It is enough to say that the share of forested lands in the country is 30 percent. This is a very important indicator. In recent years, the role of paper industry in the field economics has been highlighting the products made of wood products. Interests of Azerbaijani businesspersons in investing in various fields of Poland and mutual understanding in the business forum are examples of this. Generally, 35 percent of the workforce in the Republic of Poland are employed in agriculture. One of the highlighted points when analyzing issues in a broader sense is that Poland's interest in co-operation with the Azerbaijani companies and the desire to make investments result from interest in the production of domestic goods in the country. The economic policy pursued by the government of Azerbaijan calculated overall for diversification of the country's economy and for the development of different sectors of the economy. Steps have been taken in the liberalization of the Azerbaijani economy. Therefore, the implementation of such a process gives rise to investing and strengthening the work on this line. Involvement of investors, granting preferential loans were calculated for the development of the field economy and the prospects for its development.

The role played by the private sector in the GDP indicators is exceptionally exemplary. The independence gained by Poland and Azerbaijan does not cover much of the time. During these 27 years after the collapse of the Soviet Empire, these republics have made significant progress not only in political, but also economic. Successes in different sectors of the economy, representation in key international organizations, what is going on in the country's strategic goals, liberalization of the economy, results in export and import issues, etc. all in a short period of time exhibit a dynamic view? It is enough to say that Azerbaijan has managed to attract 200 billion investment in the last twenty years. This is a result of Azerbaijan's successful partner, the ability to shape a sense of trust in a mutual understanding. Reliable investment climate gives the basis for economic relations with Poland and Poland's willingness to invest in Azerbaijan.

Mutual relations are calculated on economic fields and holding business forums, negotiations and negotiations at the state and government levels, etc. all of which calculated for the implementation of an economic strategy. Negotiations in the transport and energy sectors are important as part of the economic block. As you know, Azerbaijani oil is delivered to Poland and the gigantic project implemented by Azerbaijan's partner countries, the Southern Gas Corridor, serves to meet the world's increasing fuel needs. Azerbaijani gas delivered through this corridor to European markets. The work of the first phase of this project is about to end and the second stage is calculated by 2020 . Azerbaijan's rich energy resources have an important function to ensure Europe's gas security.

Production of light industry, machinery and chemical industry, agrarian industry, construction materials and construction, heavy industry, shipbuilding, textile, chemical industry, metal industry, metallurgy, wood industry (combine) and furniture production, automobiles, aircraft, aluminum, wooden trousers and paper industry and so on. Mining industry plays an important role in the country's economic growth. Manganese, tin, salt, lignite and iron are of particular importance in Poland's underground resources, one of Europe's largest coal producers.

Conclusions. The study of the perspective directions of development of economic relations between the Republics of Azerbaijan and Poland has led to the emergence of scientific conclusions. These conclusions give an idea of the historical traditions of economic, cultural and political relations between Azerbaijan and Poland. As it is known, both Azerbaijan and Poland have certain ties with each other in terms of their rich history and the existence of a unique cultural environment of the ethnos. The history of these connections is mostly characterized by those from the 16th century to the present day. Since the beginning of the 19th century, it has always been in the direction of reproduction and at the same time covered various spheres of economic, cultural and political life.

Today, the relationship is characterized by various analyzes. For example, the chief architect of Baku was the Polish Josef Goslawski (late 19th and early 20th centuries), the buildings built by Plosko and Skurevich in defining the architectural image, the active participation of Poles in the formation of the Azerbaijan Democratic Republic and leading positions in government (Krichevsky brothers, General Maciej Szczecin etc.), as well as the fact that in the Second World War, the Azerbaijani Veli bey Yadigarov became a colonel of the Polish national army, etc. The study of 
economic relations between the Republics of Azerbaijan and Poland at the level of international economic relations identifies sound prospects. The processes taking place in world politics after the collapse of the Soviet empire laid the foundation for the restoration of Azerbaijan's state independence. Poland, as a state, moved away from the idea of a socialist state which entered the space of socialism, and determined the path of independent action. He began political, economic and cultural reforms in Europe. It is currently one of the most developed countries in Central Europe due to its economic potential. It is the largest member of the European Union among the members of the Eastern Bloc. As a geoeconomic space of the South Caucasus, Azerbaijan has an exceptional opportunity to meet its growing energy needs. Rich hydrocarbon fields, East-West, South-North transit function, form a solid picture for the prospects of economic and trade relations. The "one way, one belt" project, formed in the imagination of the transnational world, demonstrates the necessary position and allows for results. In this way, both Azerbaijan and Poland play a more important role in the geo-economic space in which they are represented as regional states. In addition, one of the authors of the initiative implemented by the European Union within the Eastern Partnership program is the Republic of Poland. Azerbaijan's important place in this program creates conditions for the expansion of Eastern policy, as well as economic ties.

The direction of cooperation in the non-oil sector determines the prospects for expansion in the fields of mechanical engineering, light and food industries, oil engineering, petrochemistry, chemistry, agriculture, etc. Research shows that the modernization of production, service and market infrastructure, the application of new technologies to the country's economy is important in terms of improving the living standards of the population. All this, in the end, gives grounds to say that the economic relations between Azerbaijan and Poland arose out of necessity as an example of political, cultural and historical ties, and promise substantial prospects for both countries, bringing additional benefits.

\section{REFERENCES}

1. Z. Brzezinski, The domination of America and its geostrategic imperatives Moscow, International Relations. 1998

2. La Porte, Jody (2016). "Semi-presidentialism in Azerbaijan". In Elgie, Robert; Moestrup, Sophia (eds.). Semi-Presidentialism in the Caucasus and Central Asia. London: Palgrave Macmillan (published 15 May 2016)

3. Neary, J. Peter (2004). The Stolper-Samuelson theorem (PDF). London: Centre for Economic Policy Research. Retrieved from http://users.ox.ac.uk/ econ0211/papers/pdf/stolpers.pdf

4. Sefer Shener, Ercan Saridogan, The Effects of Science-Technology-Innovation on Competitiveness and Economic Growth, Turkey, The 7th International Strategic Management Conference, 2011

5. Thomas de Waal, Black Garden: Armenia and Azerbaijan Through Peace and War. NYU press. 2003

6. Frank N. Magill, International Encyclopedia of Economics, London, 1997

7. Harvey Jask, Jovsey Ernie, Modern economics. Baku, 2008

8. Statistical Yearbook of Azerbaijan. Baku, 2014

9. Azerbaijan economic indicators. Baku, 2013

10. Soares S. M., Adam Smith an inquiry into the nature and causes of the wealth of nations, USA, New York: Metalibri, 2007

11. Scholvin S. and Wigell M., Geo-Economics as Concept and Practice in International Relations: Surveying the State of the Art, Finnish Institute of International Affairs, 27 Apr 2018 